\title{
„Rasa“ a rasismus v Jižní Africe
}

\section{„Race“ and racism in South Africa}

\author{
Hana Horáková
}

\begin{abstract}
The concept of race has been a central element of South African social reality from the late nineteenth century to the present day. Nowhere else could one come across such a systematic and rationalised social engineering stemming from the notion of human difference and based on the firm belief in the incommensurability of "races" and cultures. Modern ideology based on the idea of racial segregation of South African society coincided with the rise of social evolutionism and biological scientific racism in the late nineteenth century. For many reasons that are discussed in the text, the impact of scientific racism on South African politics has remained substantially limited. Gradually, the idea of "race" has been replaced by a politically correct concept of culture and cultural differences, which appear as incommensurable as the former concept of "races." The discredited language of "race" has made way for a fashionable culturalist discourse, yet racism has remained an essential part of post-apartheid South Africa. The text analyzes the development of segregationist policies in colonial and apartheid South Africa that were formulated and implemented both by Afrikaners and English-speaking South Africans. "Race" is examined in relation to other social-science terms such as language, ethnicity, nation and culture. Finally, the text concentrates on the policies of nonracialism that were adopted by the new political dispensation in South Africa after 1994 as a response to the racist apartheid regime that had created a deeply divided society. At the same time, new forms of racism are discussed that have emerged in post-apartheid South Africa despite the political project of nonracialism.
\end{abstract}

KEY WORDS race, scientific racism, culture, apartheid, nonracialism,

Termín „rasa“ se může prokázat neuvěřitelně odolnou existencí v čase i prostoru. Výrazy obsahující tento pojem se hojně vyskytují nejen ve veřejném životě, ale i v odborných debatách a pracích. V průběhu dějin se tento termín prolínal s dalšími sociálně vědnými pojmy, jako např́íklad „,třída“, „lid“, ,národ“, „etnická skupina“ a také „,kultura“. To, co mají všechny tyto výrazy společné, je skutečnost, že jsou odrazem důležitosti (přinejmenším symbolické) hranic v lidské společnosti (Llobera 2003: 217). Tyto hranice, jakkoli se zdají pro lidstvo potřebné, jsou zároveň manipulovatelné, posuvné, zneužitelné, dynamické, tedy nacházejí se v neustálém pohybu. Jsou to kulturní konstrukty. ${ }^{1}$

Sociální studia. Fakulta sociálních studií Masarykovy univerzity, 4/2007. S. 113-??. ISSN 1214-813X.

$1 \quad$ Koncept rasy jako kulturního konstruktu byl ovlivněn Bergerovou a Luckmanovou teorií sociální konstrukce reality (1966, česky 1999) a dále byl rozvíjen zejména v pracích autorů jako je Gilroy (1987), Fieldsová (1990, 2003), Lopez (1994), Hall (1996), Delgado (2000). Tento koncept se 
Cílem tohoto textu je analýza vývoje segregační politiky v koloniální a apartheidní Jižní Africe a postižení svébytné koncepce rasy v politice i veřejné sféře této země. „Rasa“ bude zkoumána ve vztahu k dalším sociálně vědním pojmům, jako jsou „etnicita“, „národ“ a „kultura“, které byly používány v koloniální i apartheidní Jihoafrické republice (JAR) jako klasifikační a hierarchizační jednotky. Předmětem zájmu bude následně politika nerasovosti, která se stala po roce 1994 centrálním rysem nové JAR pokoušející se překonat apartheidní dědictví hluboce rozpolcené jihoafrické společnosti. Současně budou diskutovány nové formy rasismu, jež se vynořily v jihoafrické společnosti po pádu apartheidu i přes její deklarovanou nerasovost. Názor, že lidstvo se dá třídit do kategorií a typů jako „poštovní znám$\mathrm{ky}^{\text {“ }}, 2$ má dlouhou historii, jejíž popis a interpretace nejsou předmětem tohoto textu. $\mathrm{V}$ jeho úvodu je však zapotřebí zmínit ty rasové teorie, které mají př́mou či neprrímou souvislost s konceptualizací rasy v Jižní Africe.

Problematika rasových diferencí a kategorizací byla součástí evropského myšlení dlouho před nástupem vědecké teorie ras v 19. století. Formovala se v průběhu transatlantického obchodu s otroky. Názory tehdejších Evropanů na černochy byly založeny na velmi specifických zkušenostech s kontakty s Afričany, a to jak s obchodníky s otroky na pobřeží Afriky, tak i s otroky v Novém světě. Evropané věřili, že černá barva kůže, vlasy či obličejové rysy (dnes hovoříme o fenotypu) jsou určitým způsobem spojeny s africkým způsobem života, tedy kulturou. Rasové a kulturní stereotypy se tak prolínaly. Studium rozdílností pozorovaných mezi jednotlivými populacemi se datuje od poloviny 18. století a souvisí s rozvojem evropského osvícenství a s nástupem racionalismu. Vznikající typologie a kategorizace (například Linnaeus, ${ }^{3}$ Blumenbach, Cuvier) zohledňovaly nejen poznatky biologické povahy, ale pomáhaly racionalizovat původní představy a stereotypy o „těch druhých“. Jak uvádí Curtin (1972), stereotypy Britů ohledně ,,africké povahy“ vznikaly zejména na základě cestopisných zpráv, které zdůrazňovaly zásadní rozdíly mezi evropským a africkým naturelem. Afričané byli spojováni s takovými povahovými vlastnostmi, jako je lenost, divokost, zbabělost, pověra či sexuální nezdrženlivost. ${ }^{4}$ Podle Bantona nevznikaly stereotypy o méněcennosti Afričanů ze skutečného pozorování života Afričanů ani nebyly př́imou aplikací evropských rasových doktrín. Byly vytvářeny Evropany na základě sociálních a politických potřeb bílých osadníků v afrických zemích v období koloniální expanze (Banton 1998: 93). Průkopníkem rasové

stal v nedávné době předmětem kritiky především v pracích publikujících výsledky genetických výzkumů, které oživují v minulosti překonaný názor o souvislosti rasy a biologie. V americké kulturní antropologii se touto otázkou v nedávné době zabýval např́íklad John Hartigan Jr.; srov. jeho text „The End of Social Construction“v publikaci Nationalism's Bloody Terrain, ed. George Baca, 2006.

2 Jde o parafrázi slov česko-amerického antropologa Zdeňka Salzmanna z jeho článku z roku 2003 „Existují rasy? Nový pohled na fyzickou rozmanitost lidstva“, Český lid, 90 (2): 161-170.

3 Již Carl Linnaeus, který je běžně vnímán jako jeden z prvních vědců, kteří použili koncept rasy k rozdělení lidstva do kategorií, nezakládal svou argumentaci čistě na biologických vlastnostech. Např́iklad Evropané byli mimo jiné identifikováni jako „temperamentní a tvořiví“, kdežto Afričanům Linnaeus přiřadil vlastnosti jako „lstiví, pomalí a nedbalí“ (Boonzaier 1988: 61).

4 Vedle výčtu nectností se ve zprávách objevovaly také informace o pozitivních stránkách africké povahy, jako je úcta ke starším, mírnost, ochota, někdy i ušlechtilost (Curtin 1972: 130-142). 
typologie v Británii byl Ch. H. Smith, který lidstvo dělil na tři rasy podle typu vlasů a vousů: kudrnatá (angl. woolly-haired), respektive černošská; bezvousá mongolská; a vousatá neboli indoevropská. O př́ičinné souvislosti mezi rasovými a kulturními stereotypy svědčí Smithovo přesvědčení o „hluboce zakořeněné nenávisti Indoevropana vi̊či typickému černochovi“ (Banton 1998: 68-69). K dalším britským predarwinským rasologům patřil skotský lékar̆ a milovník typologií Robert Knox, který významně rozpracoval koncept rasy v díle Rasy lidí (The Races of Men, 1850). V Jižní Africe strávil tři roky a výsledkem jeho činnosti byla klasifikace obyvatel této země na základě anatomických zvlášností, jež údajně korelovaly s národní povahou, jak dokládá podtitul jeho práce - Fyziologický vízkum vlivu rasy na osud národi̊ (A Physiological Enquiry in the Influence of Race over the Destinies of Nations). Knox svými pracemi inicioval antropometrická bádání v Jižní Africe.

Rozkvět vědeckého bádání o rase je spojován zejména s 19. stoletím, kdy došlo k největší koloniální expanzi evropských mocností. Vědecký rasismus, ${ }^{5}$ založený na kauzálním vztahu mezi fyzickými rysy a mentálními schopnostmi lidí, byl západními mocnostmi využíván $\mathrm{k}$ ideologické obhajobě jejich koloniálních výbojů. Argumentace Evropanů se opírala mimo jiné o odkazy na vrozenou tendenci k násilí, k sexuální nezdrženlivosti apod. u domorodého obyvatelstva. Jestliže předchozí rasové typologie vycházely z předpokladu, že určité typy lidí jsou vybaveny neměnnými vlastnostmi, které člověka determinují, vědecký rasismus šel ještě dál, když postuloval závislost duševních kvalit lidí na jejich fyzických vlastnostech. Kategorizace lidských populací tak znamenala rozdělení lidí nejen podle jejich tělesných znaků, ale především podle jejich kulturních specifik a intelektuálních schopností. Vědecky zjišstěné sociální diference legitimizovaly dominantní pozici Evropanů v koloniích.

Rasové teorie kulminovaly v 19. století, a jak tvrdí Budil (2002), stal se z nich nejen klíč $\mathrm{k}$ porozumění dějinám, ale i oblíbené téma ve veřejné kultuře i literatuře: např́íklad sir Walter Scott popisoval boje mezi Skoty a Angličany jako „rasové“ války. Podobně i britský premiér viktoriánské éry Benjamin Disraeli věřil, že myslet „rasově“ (angl. think racially) je moderní a vědecké (Banton 1998: 4). V Jižní Africe se rasové paradigma promítlo nejen do většny populární a akademické literatury, ale stalo se rovněž leitmotivem politických projevů. Například kapský guvernér Sir Alfred Milner, politik s neskrývanými imperiálními zájmy, sám sebe označoval za „vlastence britské rasy“ (Dubow 1995: 129).

V sociálních vědách se lze setkat s trojí formou odkazu na pojem vědecký rasismus - s uvozovkami (1), pod označením pseudovědecký rasismus (2), popřípadě bez uvozovek (3). V tomto textu je užíván termín vědecký rasismus a jeho modifikace bez uvozovek. Důvodem je přesvědčení, že i přesto, že tato teorie byla postupně označena jako nevěrohodná a posléze zcela zdiskreditovaná, mnoho tehdejšich badatelů o rase splňovalo kritéria vědecké práce té doby, a tudíž by měli být nazýváni vědci. Jak uvádí Dubow, málokoho by napadlo používat např́íklad termín alchymie jako dávno překonanou teorii v uvozovkách (Dubow 1995: 3). Naopak, v otázce užívání termínu „rasa“ jsem se přiklonila k úzu psaní v uvozovkách, protože vycházím z přesvědčení, že rasy jako ohraničené skupiny lidí neexistují. 


\section{Bělošská nadvláda v Jižní Africe}

Kulturní pluralita se dotýká celých novodobých dějin Jižní Afriky, za jejichž počátek je obecně považován rok 1652, spojený s příchodem Búrů-Afrikánců ${ }^{6}$ a založením první holandské stanice v Kapsku. Evropský přistěhovalecký prvek byl významně posílen v roce 1805, kdy Kapsko opětovně dobyli Angličané. Dějiny Jižní Afriky jsou sice poznamenány vzájemným nepřátelstvím mezi těmito dvěma skupinami evropských přistěhovalců, avšak přetrvávající antagonismus nikdy neohrozil realizaci společného cíle jak koloniálního státu, tak i pozdějšího apartheidního režimu, jímž bylo vytvoření a udržení bílé Jižní Afriky. K ukončení období bělošské dominance, trvajícího téměř 350 let, došlo počátkem devadesátých let 20. století, kdy Jihoafrická republika nastolila „,v̌erasovou“ demokracii.

Existence různých skupin, žijících na území dnešní Jihoafrické republiky, je historickou realitou. Je výsledkem tisíciletého procesu osídlování této části světa. Způsoby, jakými byla koexistence těchto skupin v průběhu historie interpretována, jsou předmětem zájmu sociálních vědců. Koncept rozdílných kultur a „ras“ byl v Jižní Africe vždy v centru pozornosti politiků. Po staletí bylo operováno s množstvím sociálně vědních pojmů, jako je „rasa“, „národ“, „etnická skupina“, „populační skupina“, „kultura“, „,tradice“, „národní stát“, „rozvoj“ či „,kulturní pluralismus“. Typickým jevem je provázanost těchto pojmů s politickou mocí. Jejich významy byly vytvářeny a přetvářeny podle politické objednávky.

\section{Rasové paradigma v Jižní Africe}

At’ již pojímáme „rasu“ jako výplod lidské imaginace či jako pseudovědeckou kategorii vysvětlující lidskou variabilitu pomocí kulturních a biologických termínů, musíme v př́padě Jižní Afriky potvrdit následující skutečnost: „rasa“ je již po tři sta let ${ }^{7}$ jedním z nejtypičtějších aspektů jihoafrické sociální reality. Snad kromě nacistického Německa bychom na mapě světa stěží našli zemi, která byla v minulosti více poznamenána myšlenkou o „rase“, než je Jižní Afrika. Politický, ekonomický a sociální status každého obyvatele JAR byl determinován doslova „od kolébky až do hrobu“ jeho př́slušností k dané „rase““ ${ }^{8} \mathrm{~V}$ této zemi došlo k bezprecedentnímu systematickému sociálnímu inženýrství, založenému na víře v nepřekročitelnost rasových, respektive kulturních odlišností. Není náhoda, že rasismus, který lze podle Skalníka (2005) jednoduše definovat jako víru v závislost duševních kvalit lidí na jejich fyzických vlastnostech, se stal běžným projevem reality v každodenním životě obyvatel JAR.

6 Termín Búr, jenž původně v holandštině označoval Nizozemce venkovského původu, odkazuje nejen k přistěhovalým Holand'anům, ale i k francouzským Huguenotům a Němcům. Dvě posledně jmenované skupiny se postupně etnicky „rozpustily“, což nebylo v „búrské/afrikánské“ minulosti nijak zvlášs' reflektováno. Termín „Búr“ byl v průběhu 19. století nahrazen pojmenováním „Afrikaner“, které výrazněji reflektovalo mýtus afrikánské etnogeneze, skupinové soudržnosti a „osudového“ vztahu tohoto etnika k Jižní Africe. Srov. Horáková 2007: 50-99.

7 S výjimkou několika desetiletí následujících po příchodu evropských usedlíků z Holandska, Německa a Francie - srov. Horáková, Národ, kultura a etnicita v postapartheidní Jižní Africe, kapitola „Afrikánci, jejich etnicita a identita“ (Horáková 2007: 50-99).

8 To i přesto, že bylo možno požádat o rekvalifikaci rasového statusu v rámci existujících apartheidních zákonů. Srov. text Emila Boonzaiera „,Rasa‘ a rasové paradigma“ (1988: 58-67). 
Moderní ideologie, založená na myšlence rasové segregace jihoafrické společnosti, vznikla v době sociálního evolucionismu a souběžného rozvoje vědecké teorie ras a biologického determinismu na konci 19 . století. ${ }^{9}$ Tato ideologie však nebyla prímým odrazem dobových teoretických konceptů. Ač jimi do jisté míry byla ovlivněna, vycházela zejména ze specifické politické a sociální reality té doby. V této souvislosti je třeba připomenout, že Jižní Afrika konce 19. a začátku 20. století byla místem mnoha významných proměn: země procházela masivní industrializací a počáteční fází urbanizace, řešila následky Anglo-búrské války, ${ }^{10}$ poprvé v historii se vážně začala zajímat o tzv. domorodý problém, který vyžadoval novou institucionální i intelektuální koncepci rasové segregace. ${ }^{11}$ Dubow (1995) tvrdí, že vývoj rasové teorie v Jižní Africe je nutné pojímat jako reakci na traumatickou konfrontaci společnosti s industriální modernitou spojenou s urbanizací a jako pokus o vyřešení této situace. Prudká proměna z rurální na průmyslovou společnost byla doprovázena standardními průvodními jevy, jako jsou proletarizace, masová chudoba, nárůst zločinnosti, šíření nemocí a rozpad tradiční společnosti. Rasová ideologie byla přímou odpovědí na toto rozčarování a intenzitu transformace jihoafrické společnosti.

\section{Koncepce rasy v Jižní Africe}

Předmětem této části textu je analýza svébytné koncepce rasy v Jižní Africe ve vztahu k vědeckému rasismu. Zdálo by se, že dějiny institucionalizované diskriminace v Jižní Africe poskytly doktríně vědeckého rasismu přesvědčivé argumenty. Uvidíme však, že vliv vědecké teorie ras na jihoafrickou politiku segregace a apartheidu zůstal značně omezen. Zároveň

9 Většina odborné literatury z konce 19. století pojednávající o fyzických a sociálních rozdílech mezi populacemi je označována jako produkt teorie sociálního darwinismu. Banton však toto přesvědčení považuje za zavádějící, když tvrdí, že neexistuje jedna jediná skupina autorů, která by sdílela společné názory a principy v této problematice. Jedinou názorově homogenní výjimku podle něho tvořili př́vrženci eugeniky. Termín eugenika byl poprvé použit britským matematikem a vědcem Sirem Francisem Galtonem jako název pro vědu o tom, jak pomocí genetiky zlepšit kvalitu „rasy“ (Banton 1998: 91).

10 Anglo-búrská válka (používají se i termíny „Druhá búrská válka“ či nejnověji „Jihoafrická válka“) propukla v roce 1899 poté, co Búrové odmítli udělit občanství Britům, kteří přicházeli do nezávislé búrské republiky Transvaal po roce 1887 v důsledku objevení zlata na Randu. Tato válka skončila kapitulací Búrů v roce 1902, která znamenala zánik búrských republik - Transvaalu i Oranžského svobodného státu. V roce 1910 se však Britové s Afrikánci dohodli na vytvoření Jihoafrické unie, která sestávala ze čtyř provincií: Kapsko, Natal, Transvaal a Oranžský svobodný stát.

11 Politika rasové segregace byla formulována v letech 1903-1905 nově zřízenou Jihoafrickou komisí pro domorodé záležitosti (South African Affairs Commission). Značnou roli v tomto procesu hrála Jihoafrická asociace pro pokrok ve vědě (South African Association for the Advancement of Science) z roku 1903, jejíž náplní byl mimo jiné etnologický výzkum zaměřený na fyzické, historické a kulturní souvislosti mezi jihoafrickými „domorodými rasami“. Ten odstartoval vlnu antropometrických měření, kterých se rovněž v roce 1925 zúčastnil americký fyzický antropolog českého původu Aleš Hrdlička. Jak uvádí Dubow (1995: 52), v letech 1905-1929 navštívila Jižní Afriku řada vlivných badatelů z Britské asociace pro pokrok vědy, která přispěla k tzv. jiho-afrikanizaci vědy (angl. termín South Africanisation of science). 
však budou poskytnuty argumenty svědčící o úzké propojenosti rasových teorií a lidových představ Jihoafričanů o „rase“, které pochopitelně zpětně ovlivňovaly politiku země.

Vědecký rasismus měl vliv na celou řadu oborů, které se v Jižní Africe rozvíjely fyzickou i kulturní antropologii, etnologii, psychologii, kriminologii, lékařství a biologii. Přelomové objevy ve fyzické antropologii ${ }^{12}$ z počátku 20. století proslavily Jižní Afriku na poli mezinárodní vědy. ${ }^{13}$ Jazyk sociálního darwinismu obohatil jihoafrickou rasovou koncepci o takové biologické metafory, jako jsou adaptace, segregace, degenerace (ve vztahu k problému africké urbanizace či k fenoménu „chudých bílých“, který bude osvětlen níže) či hybridizace (Dubow 1995: 9). Jižní Afrika se zdála být pro rozvoj výzkumu v oblasti biologie a fyzické i kulturní antropologie přímo ideální: od počátku novodobé historie této země se zde setkávaly a střetávaly různé skupiny. Jejich odlišnost, zprvu fyziognomická, byla předmětem bádání v mnoha vědeckých disciplínách. Pro-britsky orientovaný afrikánský politik, generál Jan C. Smuts, označil celý africký kontinent ve své přednášce v anglickém Oxfordu v roce 1929 za „lidskou laboratoř“ (Dubow 1995: 14). Ikonami odlišnosti se pro badatele v oblasti rasy staly dvě skupiny autochtonních obyvatel Jižní Afriky - Hotentoti neboli Khoikhoiové a Bušmeni, respektive Sanové. Jejich př́slušníci, kteří byli považováni za „nejnižší divošskou rasu“, fascinovali badatele nejen svou fyziognomií - byli dokonce srovnáváni s opicemi -, ale přitahovali je i jako předmět bádání, který na jedné straně postrádal vlastnosti civilizovaných bytostí, na druhé straně ztělesňoval osvícensko-romantickou představu ,šlechetného divocha“".

Jak již bylo naznačeno, vztah mezi vědeckou teorií ras a jihoafrickým pojetím rasové otázky je přinejmenším rozporuplný. Již v době, kdy byl vědecký rasismus na svém vrcholu, bylo standardní rozdělení lidstva do tří ras, indoevropské, mongolské a negroidní, komplikováno existencí „,nezařaditelné“ khoisanské ${ }^{14}$ populace, která se této klasifikaci vzpírala. Tato skupina byla nakonec označena za historický relikt tzv. khoisanoidní rasy, která se v Africe údajně vyskytovala ještě před příchodem černochů. Rasové paradigma Jižní Afriky rozeznávalo tři oddělené skupiny: Bušmeny, Hotentoty a Bantuy. Tato klasifikace zůstala v podstatě nedotčena až do třicátých let 20. století. „Problémem“ byli i Bantuové samotní. Na rozdíl od „černochů“, kteří byli považováni za „rasu“, Haddon (1909) označoval Bantuy za jazykově i kulturně smíšenou skupinu. ${ }^{15}$

Nemožnost založit vědeckou kategorizaci lidstva pouze na fyzických rysech přiměla Seligmana v jeho knize Rasy Afriky (Races of Africa, 1930) k prohlášení, že neexistuje „čistá“ biologická klasifikace a že je třeba přijmout klasifikaci smíšenou, vycházející z před-

12 K nejvýznamnějším objevům patří fosilní lebka „prvního člověka z Jižní Afriky“, dnes známého pod označením Australopithecus africanus, srov. Hulec 1997: 5-14.

13 Avšak poté, co byla vědecká teorie o rase zdiskreditována, se fyzická antropologie stala pro Jižní Afriku pověstným „kostlivcem ve skříni“. Po zavedení apartheidu v roce 1948 se tato země stala pro okolní svět vyvrhelem.

14 Termín „khoisanská populace“ je společným označením pro př́islušníky obou etnických skupin Khoikhoiů a Sanů. Jeho vznik byl inspirován jazykovou podobností mezi oběma skupinami. Khoisanské jazyky jsou charakteristické používáním různých typů mlaskavek.

15 Termín „Bantu“ byl režimem apartheidu oficiálně uživán až do počátku šedesátých let 20. století, kdy ho kvůli jeho rasistickým konotacím nahradil termín „African“ a později „Black“. 
pokladu, že rasové a kulturní kategorie se prolínají. Podobně argumentoval přední afrikánský etnolog a ideolog apartheidu P. J. Coertze, když tvrdil, že geneticky podmíněná kritéria rasy zahrnují i psychologické atributy, jako je intelektuální schopnost či osobnost (Coertze 1983: 34 in Boonzaier 1988: 64).

Výmluvným př́kladem svébytnosti jihoafrické rasové ideologie je rovněž dílo jihoafrického historika George M. Theala, jež hluboce ovlivňovalo společenské klima v JAR i v okolním světě až do konce čtyřicátých let 20. století. Podobně jako mnoho dalších vědců té doby byl Theal přesvědčen, že fyzické rysy různých „ras“ jsou těsně propojeny s kulturními a duševními charakteristikami. V Jižní Africe identifikoval čtyři rozdílné kategorie - Bušmeny, Hotentoty, Bantuy a Evropany -, jejichž př́íslušníci měli mít neasimilovatelné fyzické, kulturní a duševní vlastnosti. Touto kategorizací se snažil překonat předchozí pochybnosti o zařaditelnosti Khoisanů do tř́ běžně uznávaných ras.

Třicátá léta 20. století jsou v Jižní Africe spojena s první vážnou kritikou teorie rasového původu, k čemuž nemalou měrou přispěl jihoafrický antropolog Isaac Schapera. ${ }^{16}$ Ovlivněn kulturním determinismem Franze Boase, ${ }^{17}$ Schapera jako jeden z prvních sociálních antropologů zpochybnil do té doby automaticky pojímaný kauzální vztah mezi „rasou“ a kulturou. Problematika rasových rozdílů ustupovala do pozadí také vlivem prací britských sociálních antropologů, zejména Radcliffe-Browna a Malinowského. Došlo ke zpochybnění rasového paradigmatu fyzické antropologie, dělícího domorodé obyvatelstvo na ony tři výše zmíněné typy - Bušmeny, Hotentoty a Bantuy. V roce 1943 prrišla s ostrou kritikou „rasového mýtu“ jihoafrická antropoložka Hilda Kuperová, která prováděla sociálně antropologický výzkum ve Svazijsku. V článku „Jednota barvy ve Svazijsku“ (The Uniform of Colour in Swaziland) uveřejněném v roce 1943 v časopise African Studies argumentovala, že bílí, černí i barevní lidé jsou součástí jednoho lidského druhu a že neexistuje žádné vědecké zdůvodnění, podle něhož fyzické vlastnosti jednotlivých „ras“ korelují s kulturou.

Sociální a kulturní antropologie sice vyvíjela soustavný tlak na oddělení rasy od kultury jako dvou odlišných analytických konceptů, nicméně stále přetrvával vliv afrikánských etnologů, kteří používali rasové kategorie $\mathrm{k}$ ospravedlnění nadvlády bílé menšiny. Ideologie a politika segregace na bázi „rasy“ se začala formovat v prvním desetiletí 20 . století po ukončení Anglo-búrské války. Rozvíjela se zejména po vzniku Jihoafrické unie v roce 1910 a počínaje třicátými léty 20. století se stala součástí afrikánské nacionalistické doktríny. Cílem bylo zachování rasové integrity, jež se stalo imperativem segregační politiky a představovalo rovněž zásadní motivaci pro pozdější režim apartheidu. Jak tvrdí Banton, v zemích, kde docházelo k př́ímému kontaktu bělochů s černochy, nebyla vědecká doktrína ras úzce propojena

16 Schapera rovněž navrhoval pojímat Bušmeny a Hotentoty jako jednu skupinu a odvrhnout tak dosavadní teorii dvou oddělených fyzických i jazykových typů. V roce 1930 publikoval přelomovou studii The Khoisan Peoples of South Africa: Bushmen and Hottentots, v níž použil termín „Khoisan“. Jeho př́stup, v němž akcentoval jednotu a podobnost těchto dvou skupin, byl malou revolucí v prostředí, kde naopak hrály významnou roli rozdílnosti a rozmanitost.

17 Americký antropolog Franz Boas začal systematicky kritizovat rasovou teorii již kolem roku 1900. Přišel s koncepcí kultury, jež nemůže být redukována na rasové charakteristiky. Boas věřil, že dokonce některé fyzické rysy, jako např́klad tvar lebky, jsou ovlivněny environmenálními faktory (Boas 1912). 
s praxí. Na příkladu Jižní Afriky lze však argumentovat, že vědecké rasové teorie a populární představy Jihoafričanů o ,rase“ se vzájemně ovlivňovaly. Analytické pojetí rasy vycházelo z myšlenek romantického nacionalismu založených na přirozeném propojení „rasy“, jazyka, kultury a národa. Tuto koncepci si plně osvojila afrikánská intelektuální a politická elita přijetím doktríny křest’anského nacionalismu, který byl projevem odporu vůči kapitalistickému imperialismu Evropy 19. století, jenž na Afriku hleděl prizmatem exploatační koloniální politiky. Ideologie i politika afrikánského křest’anského nacionalismu byla přitom průsečíkem tří zdrojů: holandského neokalvinismu, německého romantismu a anglosaské rasové ideologie (Dubow 1995: 281).Vědecká teorie ras se tak stala součástí afrikánského nacionalistického projektu.

Oficiální rétorika předapartheidní i apartheidní Jižní Afriky, obhajující pozitivní aspekty segregační politiky, měla oslovit jak černé, tak i bílé Jihoafričany, zejména Afrikánce. Segregace údajně napomáhala předejít morálnímu úpadku dané „rasy“, který by nutně v kontaktu s „radikálně jinou“ skupinou nastal. Jinými slovy, černí se měli v duchu této vize těšit z předností rurálního života, nebot’ modernita ztělesněná „Městem“ představovala nebezpečí a morální zkázu. V urbánním prostředí, které díky rozvíjející se ekonomice a průmyslu muselo postupně pojmout i početné skupiny černých pracovníků, měly segregační zákony zamezit „rasovému“ míšení. Již v roce 1927 byl přijat zákon o nemorálnosti (Immorality Act), který zakazoval sexuální kontakty mezi Afričany a bělochy - prozatím v mimomanželských vztazích. Režim apartheidu přitvrdil a krátce po nástupu Malanovy Národní strany k moci přijal zákon o zákazu smíšených manželství (Mixed Marriages Act, 1949).

Koloniální a apartheidní stát používal v rétorice vyzdvihující homogenní prostor a fixní hranice jednotlivých kultur v průběhu času nejrůznější pojmenování pro jednotlivé skupiny obyvatel: „rasy“, „,národy“, „kultury“, „etnické skupiny“ apod. Všechny tyto pojmy se v jihoafrické sociální realitě vzpíraly jednoznačné definici. Umístění kultury/rasy/národa do prostoru bylo neodmyslitelným rysem bílé nadvlády, rysem, který umožňoval rozeznat masu ne-bílého obyvatelstva a rozdělit ji do homogenních, etnicky „ک̌istých“ území. V 19. století jihoafrický stát ještě nestačil vyvinout všechny účinné mechanismy k realizaci tohoto plánu. To se částečně změnilo ve století dvacátém, zvláště v padesátých letech poté, co byly segregační praktiky institucionalizovány. Je však třeba připomenout, že ideologie segregace byla do značné míry ovlivněna i odbornou literaturou zabývající se eugenikou, která vznikala v anglicky mluvícím intelektuálním prostředí nejen ve Velké Británii a Spojených státech, ale i v Jižní Africe. Klíčové segregační zákony, jako je zákon o půdě domorodců z roku 1913 či zákon o městských oblastech pro domorodce z roku 1923, byly přijaty vládami Jihoafrické unie, na jejichž tvorbě se výrazně podíleli anglicky mluvící jihoafričtí politici. Je tedy historicky neopodstatněné připisovat všechno zlo pramenící z ideologie a politiky apartheidu výlučně Afrikáncům, ač nelze popřít, že to byli oni, kteří po vítězství Národní strany v roce 1948 režim apartheidu institucionalizovali.

\section{Apartheidní JAR jako rasová společnost}

Paradoxem je, že po roce 1948, čili zhruba ve stejné době, kdy Západ začal přehodnocovat původní teorii o rase, postavil tehdejší apartheidní režim jihoafrickou společnost na 
vědecké koncepci rasy, tj. na víre $\mathrm{v}$ existenci uzavřených a neasimilovatelných rasových skupin, jejichž hranice jsou nepřekročitelné. Ideologie apartheidu tedy vznikla z ideje, že lidstvo lze rozdělit do různých „ras“. Rasové paradigma bylo základem obhajoby politických struktur, které se v Jižní Africe v té době vytvořily. Po druhé světové válce, kdy používání termínu „rasa“ bylo shledáváno čím dál problematičtějším, reagovala jihoafrická vláda tak, že dosavadní debatu o „rase“ opustila a zavedla novou, založenou na „etnicitě“. Rasová rétorika tak byla $\mathrm{v}$ šedesátých letech 20 . století nahrazena politickou debatou o kulturních rozdílech; došlo k posunu od „rasy“ k „,etnicitě“. Tato změna terminologie reflektovala i postupný koncepční posun. „Kultury“ či „etnické skupiny“ poskytly pro tradování mnoha základních pohledů spojených s rasovým paradigmatem úrodnou půdu. Podobně jako „rasa“ může být i „kultura“ či „etnická skupina“, je-li pojímána dostatečně staticky, použita jako klasifikační a hierarchizační jednotka. Nová ideologická vize JAR jako země multietnické se začala realizovat v 60. letech pod vedením tehdejšího premiéra Hendrika Verwoerda. Podle ní měla každá etnická skupina přiděleno určité teritorium, kde (by) mohla rozvíjet svůj potenciál a stát se „suverénním národem“ (Sharp 1988: 79). V souladu s ideologií multietnické JAR se různé etnické skupiny vzájemně lišily údajně objektivními kulturními rozdíly. Členové jednotlivých skupin hovořili odlišnými jazyky, udržovali odlišné kulturní praktiky a sdíleli odlišné systémy věr. Na základě askribovaných charakteristik měli členové etnika vlastní (společné) zájmy, které propagovali a hájili. Etnické skupiny byly v JAR modelovány na bázi rozsáhlého sociálního inženýrství. Je tedy obtížné vymezit jejich skutečné charakteristiky. ${ }^{18}$ Relevantní otázka zní, jak byla jihoafrickým obyvatelstvem tato vize státu rozděleného do separátních etnických skupin přijímána. Skutečností je, že mnozí Jihoafričané až donedávna věrili - a značná část jich stále věří -, že jejich společnost se skutečně skládá z rozdílných „rasových“ a etnických skupin, z nichž každá vytváří oddělené komunity, pyšnící se svými vlastními tradicemi a kulturou. Věřili/věrí, že tyto skupiny objektivně existují v reálném světě a že tuto skutečnost nelze změnit (Sharp 1988: 21). Kulturně a „rasově“ definované skupiny se měly podle hlavních architektů ideologie apartheidu, afrikánských intelektuálů - etnologa Eiselena a sociologa Verwoerda - rozvíjet odděleně. Soužití rozdílných skupin obyvatelstva mělo být i v budoucnosti naprosto vyloučeno, nemělo smysl pokoušet se o asimilaci, natož o integraci. Skupiny si měly spravovat své záležitosti samy (koncept „vlastních záležitostí“, afrikánský termín eie sake). Tato ideologie kulminovala v částečně úspěšném pokusu etablovat nezávislé státy pro jednotlivá černošská etnika, tzv. domoviny či bantustany, do nichž byli černí Jihoafričané systematicky přesouváni v průběhu 60. a 70. let minulého století.

Apartheid se do dějin kultury zapsal jako originální systémové řešení jihoafrického konfliktu „ras“, které všem skupinám umožní rozvíjet se odděleně, tudíž plnohodnotně, podle pravidel a norem jednotlivých kultur (anglický eufemismus separate development). Zdálo by se, že apartheid je klasický př́íklad převedení teorie do praxe. Apartheid však není přirozeným a nevyhnutelným výsledkem rasové ideologie, jak je často vnímán. Taková teze by

18 Souhlasíme-li s argumentací konstruktivisty F. Bartha, že etnicita a identita se vytvárí na základě kontextů a situací a že etnické hranice jsou záležitostí fluidní, musíme připomenout, že v čase a prostoru dochází $\mathrm{k}$ míšení etnických charakteristik, a tak k překonávání (proměně) původních identit. 
byla př́lilišným zjednodušením. Předně, jak bylo výše zmíněno, vědecká teorie ras byla spolu $\mathrm{s}$ koncepcí biologického determinismu zdiskreditována právě $\mathrm{v}$ době, kdy došlo $\mathrm{k}$ institucionalizaci apartheidu. Byla-li vědecká fakta o kategorizaci lidstva do tř́ ras do jisté míry ignorována $\mathrm{v}$ době, kdy vědecká teorie ras kulminovala, nepřekvapí, že odborná argumentace vedoucí $\mathrm{k}$ diskreditaci této teorie po druhé světové válce ${ }^{19}$ měla podobně zanedbatelný vliv jak na oficiální ideologii nadvlády bílé menšiny, tak i na lidové modely operující v rámci „rasových“ kategorií. Konec konců koncept rasy a rasismus je ve světě stále živý i přesto, že až na malé výjimky (některé sociobiologické teorie) nemá oporu ve vědě. V současné Jižní Africe - a nejen tam - je rasový diskurz politicky korektně zamaskován v nových eufemismech, jako například ve spojeních „etnické minority“, „nejnižší/nejchudší třída“ (angl. underclass) nebo „zločinnost na předměstí“ (inner-city crime). Přes výše zmíněná omezení v propojení teorie a praxe došlo přesto $\mathrm{k}$ významné proměně diskurzu o rase - změnil se slovník analytických modelů: na základě změn celosvětového společenského klimatu i vlivem Montaguova ${ }^{20}$ prohlášení o rase pro UNESCO z roku 1950 byly rasové kategorie $\mathrm{v}$ JAR nahrazeny tzv. populačními skupinami a koncepty etnických skupin. Existence „rasy“ jako biologického konceptu byla (protentokrát) završena. Původní „rasové“ rozdíly přestaly být záležitostí biologických explanací, ale byly nadále vykládány a zdůvodňovány pomocí kulturalistických a náboženských konceptů..$^{21}$

Vliv vědeckého rasismu na politiku Jižní Afriky zůstal značně omezen, jak dokládá jihoafrický antropolog Emile Boonzaier. V kontrastu $\mathrm{k}$,,intelektuálnímu ospravedlňování vědeckého rasismu se rasové paradigma v Jižní Africe vynořilo bez př́mé opory vědeckého rasismu. Podobně i zánik vědecké teorie ras nemél větši vliv na lidové modely rasových rozdílů a nadřazenosti“ "(Boonzaier 1988: 66). Př́íčiny limitovaného vlivu vědecké teorie ras lze vysvětlit několika faktory. Předně, rasové teorie formulované v Evropě a Severní Americe během uplynulých dvou století neměly univerzální charakter; vycházely z politického a společenského života společností, k nimž autoři těchto teorií a jejich čtenáři patřili (Banton 1998: 233). Podobně ani v Jižní Africe, jak uvádí Dubow (1995), nikdy neexistovala homogenní skupina vědců, kteř́ by mohli vytvořit institucionální základnu k propagaci svých teorií.

Místní příčiny nízké míry aplikace vědecké teorie ras lze vysledovat ve snaze jihoafrických politiků a vědců formulovat a rozvíjet politiku založenou na víře $\mathrm{v}$ jinakost, $\mathrm{v}$ níž fyzické rysy domnělých „populačních skupin“ měly omezenou účinnost obyvatelstvo uspokojivě kategorizovat. Rasová teorie byla citlivá na předsudky kulturní povahy, které v jihoafrické společnosti vůči „tomu druhému“ převládaly. Obhájci teorie ras byli často motivováni potřebou poskytnout tomuto předsudečnému myšlení a chování racionální bázi. Apartheidní Jižní

19 Viz např́íklad knihu Elazara Barkana z roku 1992 The Retreat of Scientific Racism.

20 Britský antropolog a humanista Ashley Montagu vydal v padesátých letech 20. století několik textů na téma „rasa“ (např́klad The Race Question, Man's Most Dangerous Myth: The Fallacy of Race), v nichž zpochybnil validitu rasy jako biologického konceptu. Jedno z jeho vyjádření (Statement on Race) se dokonce stalo oficiálním dokumentem UNESCO.

21 Typologické a segregační modely však vznikaly i v poválečném období Jižní Afriky. Zmiňme např́klad typologii Murdocka z roku 1959, v níž rozlišil pět afrických ras - bušmenskou, indoevropskou, mongoloidní, negroidní a pygmejskou (in Dubow 1995: 106), nebo kategorizaci Desmonda Clarka v díle Prehistorie jižni Afriky (The Prehistory of Southern Africa, 1959). 
Afrika může sloužit jako ilustrativní př́iklad toho, že „rasy“ neexistují a že „rasa“, „kultura“ a ,jazyk" nejsou vǐči sobě v žádném kauzálním vztahu. Tehdejší režim i přes urputnou snahu a snadnou dostupnost literatury o vědeckém konceptu rasy nebyl schopen aplikovat kategorie biologicky „čistých ras“ na měnící se společnost. Ve snaze definovat nedefinovatelné tak musel využívat aspekty socio-kulturních charakteristik. Výmluvným př́íladem je arbitrárnost definic jednotlivých „populačních skupin“ v zákoně o registraci obyvatel z 50. let apartheidní JAR. Základem definic měla být směsice tělesných charakteristik, jelikož však tyto nebyly schopné definovat Jihoafričany zcela jednoznačně, byl do zákona zakomponován i odkaz na to, ,jak je daný jedinec obecně přijímán“.22

Realita populační skladby Jižní Afriky neměla ve vědecké teorii ras př́lilišnou oporu. Šlo zejména o heterogenní skupinu obyvatelstva, jež byla pejorativně označena jako barevní (coloureds, afrikánsky kleurlinge). Jako barevní byli označováni africko-afrikánští míšenci, včetně potomků Indonézanů a Malajců, kteří žili na území Jižní Afriky za rozkvětu Východoindické společnosti. Tato skupina obyvatel vzešla ze smíšených manželství i jiných sexuálních kontaktů mezi prvními emigranty z Holandska, Německa a Francie a khoisanskými ženami nebo otrokyněmi přivezenými z Východu. Specifické společenství v rámci této skupiny tvoří tzv. kapští Malajci (Cape Malay). „Problém“ těchto osob tkví v jejich smíšeném původu, jenž se postupem doby, s tím, jak krystalizovala ideologie bílých Afrikánců o vytvoření a zachování bílé Jižní Afriky, stal překážkou v jejich touze stát se plnoprávnými občany JAR (Horáková 2007). Barevní tudíž představovali pro „rasology“ problém. Nebylo totiž možné je definovat pomocí esencialistických termínů - jak z oblasti biologie, fyzické antropologie či eugeniky. Ocitli se proto někde mezi bílými a černými, a to jak sociálně, tak „rasově“ i politicky. Navíc byli oficiálně definováni v negativních termínech, jako ne-bílí a ne-černí. Martin West uvádí v knize Jihoafrická klíčová slova z roku 1988 (South African Keywords) následující oficiální definici barevných: „osoba, která není bilá nebo černá “ (1988: 101). Nedostatek vědeckých argumentů pro jejich zařazení byl však kompenzován lidovými představami a stereotypy, které se ukázaly být výrazně odolnější než mnohé argumenty převzaté z eugeniky. Jak uvádí Dubow, dobová krásná literatura představuje bohatý zdroj pokřivené identity barevných, která byla konstruována na základě jejich údajné morální a fyzické degenerace, projevující se v opilství, sklonech ke kriminálnímu jednání, prohnanosti a lstivosti (Dubow 1995: 187).

Další problematickou skupinu tvořili tzv. chudí bílí (afrikánsky arm witmense), kteří se objevili v JAR ve dvacátých a třicátých letech 20 . století. Byla to vrstva zbídačených bělochů afrikánského původu, jež se vynořila po prohrané Jihoafrické válce. Tato skupina představovala pro ideology segregace i veřejné činitele $\mathrm{v}$ zemi naléhavý problém. Existovaly obavy, že př́padné aplikace teorií vědeckého rasismu by působily v kontextu sociálního dělení mezi bílými značně problematicky. Bylo nutné objasnit př́činy „,degenerace“ - jak byl v akademické literatuře tento problém označován -, čili toho, proč se tak početná skupina (kolem

22 Pojem „obecná přijatelnost“ (angl. general acceptance) zmiňuje Martin West v článku „Matoucí kategorie: Populační skupiny, národní státy a občanstvi““ („Confusing Categories: Population Groups, National States and Citizenship“) uveřejněném v knize South African Keywords (1988: 100-110). 
tř́i set tisíc) ocitla v bídě, když patřila k „nadřazené bílé rase“. Odborná vysvětlení nebyla pochopitelně odvozena $z$ biologie a fyzické antropologie. Mezi příčinami byly jednoznačně uvedeny historické a geografické faktory, jako třeba izolovanost jednotlivých afrikánských farem, a tudíž ztížená možnost pomoci a spolupráce mezi farmáři, nehostinné a drsné prostředí, ale i prítomnost „inferiorní bantuské rasy“ (Dubow 1995: 141).

Je zřejmé, že v Jižní Africe vznikla svébytná rasová teorie, plně vyhovující tamní politické a sociální realitě. Jedním z mnoha př́íladů specifické rasové koncepce JAR je vyjádření Eiselena, jednoho z architektı̊ apartheidu, z roku 1929. V době, kdy vědecká teorie ras ještě nebyla zpochybněna, Eiselen tvrdil, že neexistuje žádný vědecký argument podporující intelektuální podřadnost určitých ras (Boonzaier 1988: 66). Skutečností je, že na tvorbě rasové ideologie se v Jižní Africe nepodílel žádný fyzický antropolog či biolog. Idea režimu apartheidu vznikla v pracovnách jihoafrických etnologů a sociologů. Později Eiselen, již jako sekretář domorodých záležitostí ve Verwoerdově vládě, poprěl, že by byl jihoafrický rasový sentiment založen na konceptu tmavší pigmentace kůže implikující intelektuální deficit (Dubow 1995: 278). Argumentoval místo toho tím, že ideologie apartheidu vychází z nepréekročitelných kulturních rozdílností mezi jednotlivými populačními skupinami.

Dějiny Jižní Afriky ukazují, jak se „rasa“ vzpírá úzkému propojení s biologií, tedy snaze vědecky a objektivně klasifikovat Homo sapiens. Tento termín je v zásadě sociálním a politickým konceptem. Až do konce dvacátých let 20. století byl synonymem k pojmu „národ“ (včetně afrikánského „volku“), po druhé světové válce, kdy došlo vlivem holokaustu k jeho zdiskreditování, ho zcela plnohodnotně nahradil pojem „kultura“. Vztah mezi „rasou“, „kulturou“ a „národní identitou“ ovlivňoval debatu o apartheidní ideologii a zdá se, že toto propojení nebylo překonáno ani s př́chodem demokracie. O přetrvávání rasového paradigmatu a o nových formách rasismu v jihoafrické veřejné kultuře i politice proto pojedná následující podkapitola.

\section{„Rasa“ a rasismus v Nové Jižní Africe}

Se zrušením apartheidu po roce 1989 se $\mathrm{v}$ jihoafrické společnosti vynořila nová vize společnosti, jejímž cílem bylo vytvoření jednoho národa a jedné kultury. Alternativou k předchozí politice nuceného oddělení a „mezirasových“ nepřátelství se staly tři klíčové koncepty: budování národa, nerasovost a smíření (Moodley a Adam 2000: 2). „Rasa“ či „etnicita“ se měly napřiště stát irelevantními faktory $\mathrm{v}$ nově se tvořící společnosti. Jazyk politické transformace zdůrazňoval namísto spravedlnosti a odplaty kompromis a usmíření. Vynořila se idea „duhového národa“, vznikl slogan ,jeden národ, mnoho kultur“ (srov. Horáková 2007).

Jižní Afrika skutečně vytvořila iluzi „rasové“ harmonie, a to zejména díky nekrvavé cestě od režimu apartheidu k demokracii. Vznik Nové Jižní Afriky je spojen s rokem 1994, kdy došlo k prvním „všerasovým“ volbám. Tento malý zázrak (ang. small miracle), jak je relativně nenásilný přechod od apartheidu $\mathrm{k}$ demokracii v populární i odborné literatuře nazýván, je možné vnímat i jako hozenou rukavici všem, kteří Jižní Africe předpovídali „mezirasový masakr“. Dokládá totiž, že i přes extrémně striktní „rasové“ hranice a následnou segregaci společnosti, včetně dědictví obrovských sociálních nerovností, je možné dospět $\mathrm{k}$ určitému stupni národní jednoty a $\mathrm{k}$ vizi společných zájmů, jakkoli je idea jednoho národa diskutabilní a její realizace obtížně dosažitelná (Banton 1998: 210). 
Nová politická garnitura zvolila za základ budování státu princip nerasovosti (anglický termín nonracialism). Jižní Afrika tak vyřešila dilema spočívající mezi ideálem „barvosleposti“ (colour-blindness) a potřebou operovat s pojmem „rasa“ při zmírňování reality dřívějších nerovností. Zvolila druhou alternativu, při níž využívá jak politiku pozitivní diskriminace, tak i zavádění rasového monitoringu. Ironií je, že politika pozitivní diskriminace jako součást vládního programu nerasovosti, výlučně zaměřená na jednu „populační skupinu“, tedy bílé, je závislá na používání „rasových“ schémat, na jejichž základech jihoafrická společnost spočívala $v$ minulosti.

Pojem nerasovosti, tak jako i další sociálně vědní termíny, je mnohovýznamový. Jihoafričané zaujímají $\mathrm{k}$ projektu nerasovosti nejrůznější postoje. Ty v dnešní JAR zahrnují přehnaně optimistická očekávání, spojená s euforií a iluzí národního smíření, kterou vyprodukovala Komise pravdy a usmíření (Truth and Reconciliation Commission, TRC) a veřejné vystupování bývalého prezidenta Nelsona Mandely. Jiné postoje jsou spíše skeptické až odmítavé, nebot' u určitých vrstev jihoafrické populace již došlo k vystř́zlivění z euforie, kterou vystř́ídalo rozčarování, netrpělivost až deziluze. Jinými slovy, někteří chápou nerasovost jako výzvu pro tzv. historicky znevýhodněné vrstvy umožňující jim podílet se na prosperitě země, jako automatické právo př́stupu všech obyvatel ke všem zdrojům; jiní v ní spatřují politickou dominanci v kulturním převleku, tj. hegemonii černých Jihoafričanů spjatou s jejich útoky na kulturu ostatních, ne-černých skupin obyvatel.

Jihoafrický ideál nerasové společnosti, který je dokonce zakotven v ústavě z roku 1996, je v dnešním světě vizí romantickou a unikátní. Nepřekvapí zjištění, že tento ideál není v současné JAR naplňován. Místo toho bují diskurz o rase snad ještě intenzivněji než v dobách institucionalizovaného rasismu. „Rasa“ je nejenom nástrojem získávání pozic v otevřené soutěži, ale slouží také jako kamufláž problémů; téměř každá kritika vlády Afrického národního kongresu (ANC) je označena za rasistickou a jako taková odmítána. Ilustrativní ukázkou principu nerasovosti jsou jihoafrické volby; od prvních všeobecných voleb z roku 1994 až po třetí volby v roce 2004 Jihoafričané volili převážně podle „rasového“ a etnického klíče (racial and ethnic voting), ač všechny politické strany deklarují rasově smíšené zastoupení.

„Rasa“ je v JAR nadále klíčovým faktorem populační kategorizace. Jestliže političtí lídři, náboženští představitelé a média používají ve svých vyjádřeních reference k populačním kategoriím „bílý‘, „barevný“ atd., těžko se lze divit, že tyto pojmy jsou považovány za zcela legitimní i v dalších vrstvách společnosti. Emile Boonzaier ve svém článku z roku 1988 napsal, že „tento termín je součástí našeho běžného, každodenního slovníku. Slyšíme ho $\mathrm{v}$ rádiu a televizi, čteme o něm $\mathrm{v}$ novinách a časopisech, uživáme ho každý den v debatách. A i když není ,rasa‘ explicitně užita, je jasné, že myšlenky a domněnky o vrozených rasových rozdílech prostupují valnou část našeho myšlení“ (Boonzaier 1988: 58). Od Boonzaierovy výpovědi uběhlo téměř dvacet let, z čehož třináct let Jižní Afrika buduje demokracii. Popis současné každodenní reality se však od Boonzaierovy původní interpretace nikterak neliší. Dochází paradoxně k situaci, že se zánikem institucionalizovaného rasismu je novodobá společnost zachvácena rétorikou „ras“ snad ještě více než v minulém režimu. Navíc nedochází k potřebné sociální integraci nejen mezi běžnou populací, ale ani u elit. Skutečností je, že určitá forma „nerasové“ identity se ve veřejném prostoru začíná objevovat. Jde například 
o kulturně-hudební styl kwaito, ${ }^{23}$ hip-hop, některé žánry literatury, domácí mýdlové opery a některé experimentální divadelní scény. Avšak tyto nově vznikající identity nelze oddělit od daných materiálních podmínek, které jsou minulým dědictvím. Jsou to zejména materiální faktory a výrazná ekonomická nerovnost, které znemožňují integraci jihoafrického obyvatelstva, a tím vytvoření nových „nerasových“ identit. Jihoafrická společnost zůstává i přes vládní proklamace geograficky, sociálně i kulturně rozdělena podle předchozích „rasových“ linií.

Myšlení o „rase“ prostoupilo všemi vrstvami jihoafrického obyvatelstva, nehledě na jejich podřízené či dominantní postavení ve společnosti. Bylo by samožrejmě velice naivní se domnívat, že za tak krátkou dobu dojde k viditelné transformaci lidských myslí. Zkušenosti z postkomunistických zemí ukazují, jak houževnaté jsou staré styly uvažování včetně víry v existenci zvláštní romské či židovské „rasy“, a jak obtížné je jejich nahrazení styly novými. Jde o dlouhodobý úkol, se kterým se bude potýkat přinejmenším několik nastupujících generací. Naskýtá se otázka, zda je vhodné i nadále termín „rasa“ používat. Jak ukazuje Dubow, existuje mnoho důvodů, proč tento termín vyřadit ze slovníku: jeho chybné používání, nerozlišování mezi „rasou“, „etnicitou“ a „kulturou“ apod. (Dubow 1995: 179). Na druhé straně, pokus bojovat proti rasismu tím, že se veřejně „zapomene“ na „rasu“, náboženství a národnost, inicioval v minulosti posun ke konceptu etnicity, který je stal neméně palčivým problémem jihoafrické společnosti.

Van den Berghe označil režim Jižní Afriky za apartheidu jako „Herrenvolk democracy“, což je společnost, která je demokratická pouze ve vztahu k dominantní „rase“, v prŕípadě JAR k bílým. Vůči podřízeným „rasám“ je despotická (Llobera 2003: 228). Taková společnost je charakterizována institucionalizovanou formou vykořist’ování a diskriminací na bázi „rasy“. Studie prokázaly, že společnost tohoto typu má tendenci rasové předsudky nejprve internalizovat a poté racionálně zdůvodňovat. Rasové společnosti se vyznačují př́ísnou stratifikací a hierarchizací. Znamená to, že členové jednotlivých skupin, klasifikovaných podle jednotlivých „ras“, musejí své pozice nacházet v rigidním systému, který určuje, jaký sociální a ekonomický status získají či jaká politická práva mohou využívat. Takový typ společnosti je ze základu velmi antagonistický, a tak neustále hrozí rasový konflikt. Tyto společnosti proto kladou velký důraz na prevenci, jak př́ípadnému konfliktu předejít či jak ho zpacifikovat. Pro první př́ípad využívá mocenský aparát ideologii legitimizující samotný rasový základ společnost. $V$ druhém př́ípadě je prioritou vládní politiky vnitřní bezpečnost země, založená na spolupráci ozbrojených složek a policie.

Úvaha, že rasismus je ideologií pouze „bílé moci“ (herrenvolkismus), je zavádějící a nereflektuje komplexní charakter rasovosti či rasismu. Projevy rasové diskriminace nejsou vlastní pouze „nadřazené“ vrstvě společnosti a nejsou orientovány pouze vi̊či černým.

23 Kwaito je oblíbenou formou populární hudby černošských sídlišt', vyhledávanou především mladými Afričany. Tento nový styl se na jihoafrické hudební scéně vynořil na počátku devadesátých let 20. století. Jeho název je odvozen od afrikánského slova „rozzlobený/naštvaný“; ve slangu sídliště označuje něco žhavého/rozpáleného, něco, co se právě děje. Tento styl je charakterizován nejen vyjádřením hudebním (stále se opakující text podepřený pomalým tempem se silnými perkusemi), ale též typickým vzhledem (specifický styl oblékání mladé generace černých ve městech). 
Diskriminace na bázi „rasy“ jde všemi směry a postihuje nejrůznější skupiny lidí, které „provokuji“" svou jinakostí. Ta se může projevit různým způsobem: údajnou schopností ovládat tento svět ekonomicky a politicky (diskriminace Židů), úspěšností v podnikání v zemích, kde většinová populace strádá. ${ }^{24} \mathrm{~V}$ Jižní Africe se v současné době mluví o „rasismu naruby“, tj. jevu, kdy jsou bílí Jihoafričané diskriminováni na základě toho, že patří k „,bílé rase“. Avšak ti, kteří tento termín používají, se rekrutují právě z vrstev bílého obyvatelstva, postiženého nejvíce politikou pozitivní diskriminace. Naopak černí komentátoři mohou některé praktiky zmíněné politiky kvót považovat za diskriminační, ale jistě ne za rasistické. $Z$ uvedeného je zřejmé, jak je rasismus či rasovost významově mnohoznačným konceptem, a to i v rámci jednoho státu.

S prríchodem prvních evropských přistěhovalců do Jižní Afriky a jejich střetávání s neevropským obyvatelstvem je třeba rasismus lokalizovat do politické sféry jako ideologii či systém věr a praktik, jež se odvíjely od konceptu „rasy“ jako nástroje pro kategorizaci přirozených rozdílů mezi lidskými populacemi. Ze sféry politiky se princip rasovosti postupně presunul k sociokulturním a ekonomickým praktikám života jednotlivých „,populačních skupin.“ Pro Jižní Afriku bylo typické splývání biologických charakteristik domnělých „ras“ s kulturními a dalšími ne-fyzickými charakteristikami. Dědictví apartheidní partikularistické politiky se v Nové Jižní Africe střetává s vládním univerzalistickým projektem, jehož cílem je vytvoření jednoho národa a jedné kultury. Normy, hodnoty a názory Jihoafričanů, internalizované v procesu bílé nadvlády, jsou v kontrastu s tvorbou nových hodnotových systémů, které mají na rozdíl od předchozí rétoriky oddělených „ras“ a „kultur“ akcentovat kulturní integraci a inkluzivní charakter politiky. Protipólem dřívější separace je v současné době fenomén budování národa, nerasovost a smírení. Ve všech sférách jihoafrické sociální reality však dosud přetrvává silné dědictví apartheidu, a to jak u elit, tak u řadových občanů. Ideál nerasovosti není naplňován, rasové paradigma přežívá v latentní formě: kódovaný jazyk „,skupin“, „národa“ a „kulturní identity“ zůstává v platnosti jak v oficiálních programech a prohlášeních, tak i v lidových modelech. Praktiky a projevy rasovosti se staly součástí společné kultury, sdílené všemi vrstvami společnosti. Zdiskreditovaný jazyk „rasy“ sice ustoupil módnímu kulturalistickému diskurzu, avšak rasismus zůstává nedílnou součástí reality postapartheidní jihoafrické společností. Tento fakt představuje pro Jihoafričany jednu z nejtěžších překážek na cestě k budování „nerasové“ demokracie.

\section{Literatura}

Baca, G. (ed.) 2006. Nationalism's Bloody Terrain: Racism, Class Inequality, and the Politics of Recognition. New York and Oxford: Berghahn Books.

Banton, M. 1998. Racial Theories. 2. vyd. Cambridge: Cambridge University Press.

Barkan, E. 1992. The Retreat of Scientific Racism: Changing Concepts of Race in Britain and the United States. Cambridge: Cambridge University Press.

24 Libanonští obchodníci v zemích západní Afriky jsou často terčem fenoménu obětního beránka (angl. termín scapegoating), tj. označení ,jiného“ jako prŕčiny nezdaru. 
Berger, P. L.; Luckman, T. 1999. Sociální konstrukce reality. Pojednání o sociologii vědění. Brno: CDK.

Berghe van den, P. 1978. Race and Racism. New York: Wiley.

Boas, F. 1912. Changes in the Bodily Form of Descendants of Immigrants. American Anthropologist, 14: 3 .

Boonzaier, E. 1988. „Race“ and the race paradigm.“ In E. Boonzaier, J. Sharp. South African Keywords: the Uses and Abuses of Political Concepts. Cape Town: David Philips, s. 58-67.

Boonzaier, E.; Sharp, J. (eds.) 1988. South African Keywords: the Uses and Abuses of Political Concepts. Cape Town: David Philip.

Budil, I. T. 2002. Od prvotniho jazyka k rase. Praha: Academia.

Clark, D. 1959. The Prehistory of Southern Africa. Harmondsworth.

Coertze, P. J. 1983. Die Afrikanervolk en die Kleurlinge. Pretoria: Haum.

Curtin, P. D. 1972. British Images of Africans in the Nineteenth Century. In P. Baxter, B. Sansom ed. Race and Social Difference. Harmondsworth, Middlesex: Penguin Books, s.130-142.

Delgado, R. 2000. „Storytelling for Oppositionists and Others. A Plea for Narrative.“ In R. Delgado, J. Stefancic ed. Critical Race Theory: The Cutting Edge. Philadelphia: Temple University Press, s. 60-70.

Dubow, S. 1995. Scientific Racism in Modern South Africa. Cambridge: Cambridge University Press.

Fields, B. 1990. Slavery, Race, and Ideology in the United States of America. New Leftist Review, 181: 95-118.

Fields, B.J. 2003. Of Rogues and Geldings. American Historical Review 108, 5: 1397-1405.

Gilroy, P. 1987. There Ain't No Black in the Union Jack. Chicago: University of Chicago Press.

Haddon, A. C. 1909. The Races of Man and their Distribution. London.

Hall, S. 1996. „New Ethnicities.“ In Stuart Hall: Critical Dialogues in Cultural Studies. D. Morley, K.H. Chen. London: Routledge, s. 441-449.

Hartigan Jr., J. 2006. „The End of Social Construction.“ In Nationalism's Bloody Terrain: Racism, Class Inequality, and the Politics of Recognition, ed. G. Baca. New York and Oxford: Berghahn Books, s. 95-108.

Hervik, P. (ed.) 2004. The New Racism in Europe. Special issue of Ethnos, 9(2).

Knox, R. 1862. The Races of Men: A Physiological Enquiry in the Influence of Race over the Destinies of Nations. 2. vyd. London.

Kuper, H. 1943. The Uniform of Colour in Swaziland. African Studies 2.

Horáková, H. 2007. Národ, kultura a etnicita v postapartheidní Jižní Africe. Hradec Králové: Gaudeamus.

Hulec, O. 1997. Dějiny Jižní Afriky. Praha: Nakladatelství Lidových novin.

Llobera, J. R. 2003. An Invitation to Anthropology: The Structure, Evolution and Cultural identity of Human Societies. Oxford: Berghahn Books.

Montagu, A. 1950. Statement on race: An extended discussion in plain language of the UNESCO statement by experts on race problems. New York: Schuman. 
Moodley, K.; Heribert, A. 2000. Race and Nation in Post-Apartheid South Africa. Politics and Economics 30. University of Leipzig Papers on Africa, s. 1-13.

Murdock, G. P. 1959. Africa: Its Peoples and their Cultural History. New York.

Salzmann, Z. 2003. Existují rasy? Nový pohled na fyzickou rozmanitost lidstva. Český lid, 90 (2): 161-170.

Seligman, Ch. G. 1966. Races of Africa. 4.vyd. London: Oxford University Press.

Sharp, J. 1988. „Ethnic group and nation. The apartheid vision in South Africa.“ In E. Boonzaier, J. Sharp (eds.). South African Keywords. Cape Town: David Philips, s. 79- 99.

Schapera, I. 1930. The Khoisan Peoples of South Africa: Bushmen and Hottentots. London.

Skalník, P. 2005. „Mnoho tváŕí rasismu: výzva pro všechny antropology a etnology. Referát na Interkongresu IUAES v Pardubicích.“ In Racism's Many Faces: Challenge for All Anthropologists and Ethnologists. Book of abstracts: IUAES Inter-Congress 2005. Pardubice: Universita Pardubice.

Theal, G.M. 1887. History of the Boers in South Africa. London.

West, M. 1988. „Confusing categories: Population groups, national states and citizenship.“ In E. Boonzaier, J. Sharp (eds.). South African Keywords. Cape Town: David Philips, s. $100-110$.

\section{Autorka}

Hana Horáková je sociální antropoložka a afrikanistka. Působí na univerzitách v Hradci Králové a Pardubicích. K jejím odborným zájmům patří antropologie kolonialismu a postkolonialismu, teorie kultury ve společenských vědách, antropologie turismu a antropologie Evropy. Opakovaně prováděla antropologické terénní výzkumy v Jižní Africe, studuje také rurální společenství v České republice a Polsku. Publikuje doma i v zahraničí v oblasti afrických studií a sociální antropologie. Je mj. autorkou monografie s názvem Národ, kultura a etnicita v postapartheidní Jižní Africe (2007).

Kontakt: hana.horakova@uhk.cz; hana.horakova@upce.cz 